\title{
Disaccharidase levels in normal epithelium of the small intestine of rats with iron-deficiency anemia
}

\author{
M.I.M. Fernandes ${ }^{1}$, \\ L.C. Galvão ${ }^{1}$, \\ M.F. Bortolozzi ${ }^{1}$ \\ W.P. Oliveira ${ }^{1}$, \\ S. Zucoloto ${ }^{2}$ and \\ M.L.P. Bianchi ${ }^{3}$
}

\author{
'Departamento de Puericultura e Pediatria and ${ }^{2}$ Departamento de Patologia, \\ Faculdade de Medicina de Ribeirão Preto, Universidade de São Paulo, \\ 14045-900 Ribeirão Preto, SP, Brasil \\ ${ }^{3}$ Departamento de Análises Clínicas, Toxicológicas e Bromatologia, \\ Faculdade de Ciências Farmacêuticas de Ribeirão Preto, \\ Universidade de São Paulo, 14049-900 Ribeirão Preto, SP, Brasil
}

\section{Correspondence \\ M.I.M. Fernandes \\ Departamento de Puericultura \\ e Pediatria, FMRP, USP \\ Campus Universitário \\ Av. Bandeirantes, 3900 \\ 14045-900 Ribeirão Preto, SP \\ Brasil}

Publication supported by FAPESP.

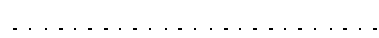

Received August 16, 1996

Accepted May 14, 1997

\begin{abstract}
Iron-deficiency anemia is the nutritional deficiency most frequently occurring throughout the world, which manifests as a complex systemic disease involving all cells, affecting enzyme activities and modifying protein synthesis. In view of these considerations, the objective of the present study was to determine the effects of irondeficiency anemia on disaccharidases and on the epithelial morphokinetics of the jejunal mucosa. Newly weaned male Wistar rats were divided into 4 groups of 10 animals each: C6w received a standard ration containing $36 \mathrm{mg}$ elemental iron per $\mathrm{kg}$ ration for 6 weeks; E6w received an iron-poor ration $(5-8 \mathrm{mg} / \mathrm{kg}$ ration) for 6 weeks; $\mathrm{C} 10 \mathrm{w}$ received an iron-rich ration $(36 \mathrm{mg} / \mathrm{kg}$ ration) for 10 weeks; E10w received an iron-poor ration for 6 weeks and then an iron-rich ration $(36 \mathrm{mg} / \mathrm{kg})$ for an additional 4 weeks. Jejunal fragments were used to measure disaccharidase content and to study cell proliferation. The following results were obtained: 1) a significant reduction $(\mathrm{P}<0.001)$ of animal weight, hemoglobin $(\mathrm{Hb})$, serum iron and total iron-binding capacity (TIBC) in group E6w as compared to $\mathrm{C} 6 \mathrm{w}$; reversal of the alterations in $\mathrm{Hb}$, serum iron and TIBC with iron repletion $(\mathrm{E} 10 \mathrm{w}=\mathrm{C} 10 \mathrm{w})$; animal weights continued to be significantly different in groups E10w and C10w. 2) Sucrase and maltase levels were unchanged; total and specific lactase levels were significantly lower in group E6w and this reduction was reversed by iron repletion $(\mathrm{E} 10 \mathrm{w}=\mathrm{C} 10 \mathrm{w}) .3)$ The cell proliferation parameters did not differ between groups. On the basis of these results, we conclude that lactase production was influenced by iron deficiency and that this fact was not related to changes in cell population and proliferation in the intestinal mucosa.
\end{abstract}

Key words

- Disaccharidases

- Anemia

- Iron deficiency

- Intestinal mucosa 


\section{Introduction}

Over the last few years, iron-deficiency anemia has come to represent the major nutritional disorder of children all over the world, especially in underdeveloped countries (1-3). In Brazil, studies on children have shown a 22.7 to $54.9 \%$ prevalence of iron-deficiency anemia, mainly depending on the characteristics of the population studied $(4,5)$. It has been demonstrated that this type of deficiency affects growth, mental performance, muscle capacity, thermogenesis, and immunity (6-8). As far as the digestive tract is concerned, irondeficiency anemia is known to be associated with stomatitis and glossitis (9-12), with reduction of gastric acid secretion (13), abnormal absorption (14), and changes in intestinal permeability (15).

Hoffbrand and Broitman (16), in 1969, studied the activity of jejunal disaccharidases in dogs with iron-deficiency anemia and demonstrated a reduction in the activity of these enzymes as compared to control groups. Sriratanabam and Thayer (17) and Lanzkowsky et al. (18) obtained similar results with rats. The first study (17) also detected disaccharidase activities similar to control values in groups of animals with protein malnutrition, and no altered disaccharidase levels in a fourth group in which protein deficiency was associated with irondeficiency anemia. Reduced disaccharidase activity was also observed in anemic children in another study (19), although the results were inconclusive.

The mechanism of reduction in disaccharidase levels in this nutritional disorder has not been elucidated since histological findings usually are normal. In 1987, Ranasinghe et al. (12), studying cell proliferation of cheek pouch epithelium in hamsters with iron-deficiency anemia, detected a significant reduction of the mitotic index (MI).

Thus, the objective of the present study was to determine disaccharidase deficiency in anemic rats in an attempt to identify the mechanism of this deficiency by the study of cell proliferation in the small bowel of these animals.

\section{Material and Methods}

The study was conducted on 40 newly weaned 21-day old male Wistar rats from the Central Animal House of the Faculty of Medicine of Ribeirão Preto, University of São Paulo.

Iron-poor ration was prepared according to the norms of the Association of Official Chemists, with the nutrient percentages and mineral and vitamin mixture composition recommended by NAS (20), and with no iron added. Balanced ration was prepared by adding ferrous sulfate to the previous ration in amounts that would supply $36 \mathrm{mg}$ elemental iron per $\mathrm{kg}$ ration. To obtain rations with these concentrations, $0.1787 \mathrm{~g}$ heptahydrate ferrous sulfate was added to each $\mathrm{kg}$ of ration.

The animals belonging to the iron-deficient group were divided into two subgroups of 10 animals each that received water and iron-poor ration $(5-8 \mathrm{mg}$ iron $/ \mathrm{kg}$ ration) $\mathrm{ad}$ libitum for 6 weeks, after which they were considered to be iron deficient and anemic (hemoglobin $<7 \mathrm{~g} / \mathrm{dl})(21,22)$. The first subgroup (E6w) was sacrificed after this period of time. The animals were anesthetized with ether and submitted to xipho-pubic opening of the abdomen, and blood was collected by heart puncture for the determination of hemoglobin $(\mathrm{Hb})$, hematocrit $(\mathrm{Ht})$, serum iron, total iron-binding capacity (TIBC) and total proteins. The small intestine was removed for disaccharidase measurements and a jejunal fragment was obtained for the study of cell proliferation. The second subgroup (E10w) then started to receive the same ration as the control group for 4 weeks, when hemoglobin levels were considered to be normal (18), and sacrificed and examined as the previous group.

The control group consisted of 20 animals divided into two subgroups (C6w, 
C10w) of 10 animals each receiving food and water ad libitum. The ration contained normal iron levels. The control subgroups were sacrificed after 6 and 10 weeks, respectively, and investigated in the same manner as the iron-deficient subgroups.

The following hematologic determinations were performed: $\mathrm{Hb}$ by the cyanomethemoglobin method (23), Ht (24), serum iron (25) and TIBC (26) by the ferrozin method, and total proteins by the biuret method (27).

The small intestine was used for disaccharidase measurement by the method of Dahlqvist (28), and for the determination of cell population and cell proliferation.

The results of the intestinal disaccharidases are reported as units (U). One unit is defined as the ability to hydrolyze $1 \mu \mathrm{mol}$ disaccharides per minute at $37^{\circ} \mathrm{C}$. The activity detected in the entire small intestine was considered to be total activity and the activity per gram intestinal wet weight is reported as specific activity.

For the study of cell proliferation, arrest of cell division was induced at metaphase: half of the animals in each group were injected intraperitoneally with $1 \mathrm{mg}$ vincristine sulfate (Oncovin, Ely Lilly do Brasil Ltda.) per kg body weight and sacrificed 2.5 $h$ later $(29,30)$. The remaining animals did not receive vincristine sulfate and were used to determine basal mitotic index.

A fragment measuring approximately 1 $\mathrm{cm}$ was removed from the first portion of the jejunum for counts of villus and crypt cell populations and of number of mitoses. These parameters were used to determine the mitotic index and cell production rate $(31,32)$. Opened jejunum segments were stretched on a sheet of white paper, fixed in Carnoy solution for $3 \mathrm{~h}$, and stored in $70 \%$ ethanol until the time for paraffin embedding. The material was then cut into serial sections perpendicular to the serosa. Only longitudinally sectioned villi and crypts were selected for the study of number of interphase cells in one hemivillus or hemicrypt and number of mitoses in each villus or crypt. Counting was performed with the aid of a 40X objective and a 10X ocular micrometer.

The MI, representing the percentage of cells in mitosis in the crypt, was calculated as follows: $\mathrm{MI}=$ number of mitoses $\mathrm{x} 100$ $\mathrm{kT} /$ total number of cells, where $\mathrm{kT}$ is the Tannock factor (33).

Cell production rate was the difference between mitotic index, calculated by blockade at metaphase by vincristine sulfate, and basal mitotic index divided by $2.5 \mathrm{~h}$ (duration of blockade by the cytostatic agent). Thus, the cell production rate expresses the accumulation of cells per hour. Data were analyzed statistically by the nonparametric Mann-Whitney test, with the level of significance set at $1 \%$ (34).

\section{Results}

Table 1 shows animal and intestinal weights for the 4 groups studied, as well as

Table 1 - Effect of iron deficiency on animal weight, intestinal weight, hematocrit $(\mathrm{Ht})$, hemoglobin $(\mathrm{Hb})$, serum iron (Fe), total iron-binding capacity (TIBC) and total proteins (TP) for groups E6w (anemic), E10w (anemic and recovered), and controls (C6w and C10w).

Data are reported as median and minimum and maximum values, within parentheses, for 10 rats in each group. $6 \mathrm{w}$ and $10 \mathrm{w}=$ No. of experimental weeks. ${ }^{*} \mathrm{P}<0.01$ compared to the respective control (nonparametric Mann-Whitney test).

\begin{tabular}{|c|c|c|c|c|}
\hline & E6w & C6w & E10w & C10w \\
\hline Animal weight (g) & $\begin{array}{c}223.5^{*} \\
(203-251)\end{array}$ & $\begin{array}{c}310.5 \\
(286-342)\end{array}$ & $\begin{array}{c}314^{*} \\
(288-372)\end{array}$ & $\begin{array}{c}399 \\
(337-431)\end{array}$ \\
\hline Intestinal weight (g) & $\begin{array}{c}7.09 \\
(5.45-9.02)\end{array}$ & $\begin{array}{c}7.03 \\
(5.86-9.27)\end{array}$ & $\begin{array}{c}6.40 \\
(5.33-7.75)\end{array}$ & $\begin{array}{c}6.38 \\
(4.43-7.48)\end{array}$ \\
\hline $\mathrm{Hb}(\mathrm{g} / \mathrm{dl})$ & $\begin{array}{c}6.00^{*} \\
(4.5-6.7)\end{array}$ & $\begin{array}{c}15.10 \\
(14.0-17.0)\end{array}$ & $\begin{array}{c}15.00 \\
(14.7-15.9)\end{array}$ & $\begin{array}{c}15.70 \\
(14.3-15.9)\end{array}$ \\
\hline $\mathrm{Ht}(\%)$ & $\begin{array}{c}24.0^{*} \\
(21.0-28.0)\end{array}$ & $\begin{array}{c}46.0 \\
(44.0-51.0)\end{array}$ & $\begin{array}{c}49.00 \\
(47.0-51.0)\end{array}$ & $\begin{array}{c}47.50 \\
(45.0-53.0)\end{array}$ \\
\hline $\mathrm{Fe}(\mu \mathrm{g} \%)$ & $\begin{array}{c}26.00^{*} \\
(19.0-44.0)\end{array}$ & $\begin{array}{c}132.5 \\
(110.0-221.0)\end{array}$ & $\begin{array}{c}150 \\
(112.0-237.0)\end{array}$ & $\begin{array}{c}158.0 \\
(113-210)\end{array}$ \\
\hline TIBC ( $\mu \mathrm{g} \%)$ & $\begin{array}{c}860.50^{*} \\
(764.0-898.0)\end{array}$ & $\begin{array}{c}556.5 \\
(426.0-718.0)\end{array}$ & $\begin{array}{c}496.50 \\
(428.0-508.0)\end{array}$ & $\begin{array}{c}523.5 \\
(418.0-620.0)\end{array}$ \\
\hline TP (g\%) & $\begin{array}{c}5.9 \\
(5.60-6.20)\end{array}$ & $\begin{array}{c}6.10 \\
(5.90-6.70)\end{array}$ & $\begin{array}{c}6.15 \\
(5.60-6.80)\end{array}$ & $\begin{array}{c}6.50 \\
(5.70-6.70)\end{array}$ \\
\hline
\end{tabular}


the results of the laboratory tests performed, i.e., $\mathrm{Hb}, \mathrm{Ht}$, serum iron, TIBC, and total proteins. Significant differences were detected between groups C6w and E6w for the following parameters: animal weight, $\mathrm{Hb}$, $\mathrm{Ht}$, serum iron and TIBC. Groups $\mathrm{C} 10 \mathrm{w}$ and E10w differed significantly only in terms of animal weight.

The medians and minimum and maximum values of total and specific lactase, sucrase and maltase activities are presented in Figure 1. Lactase activity differed signifi-
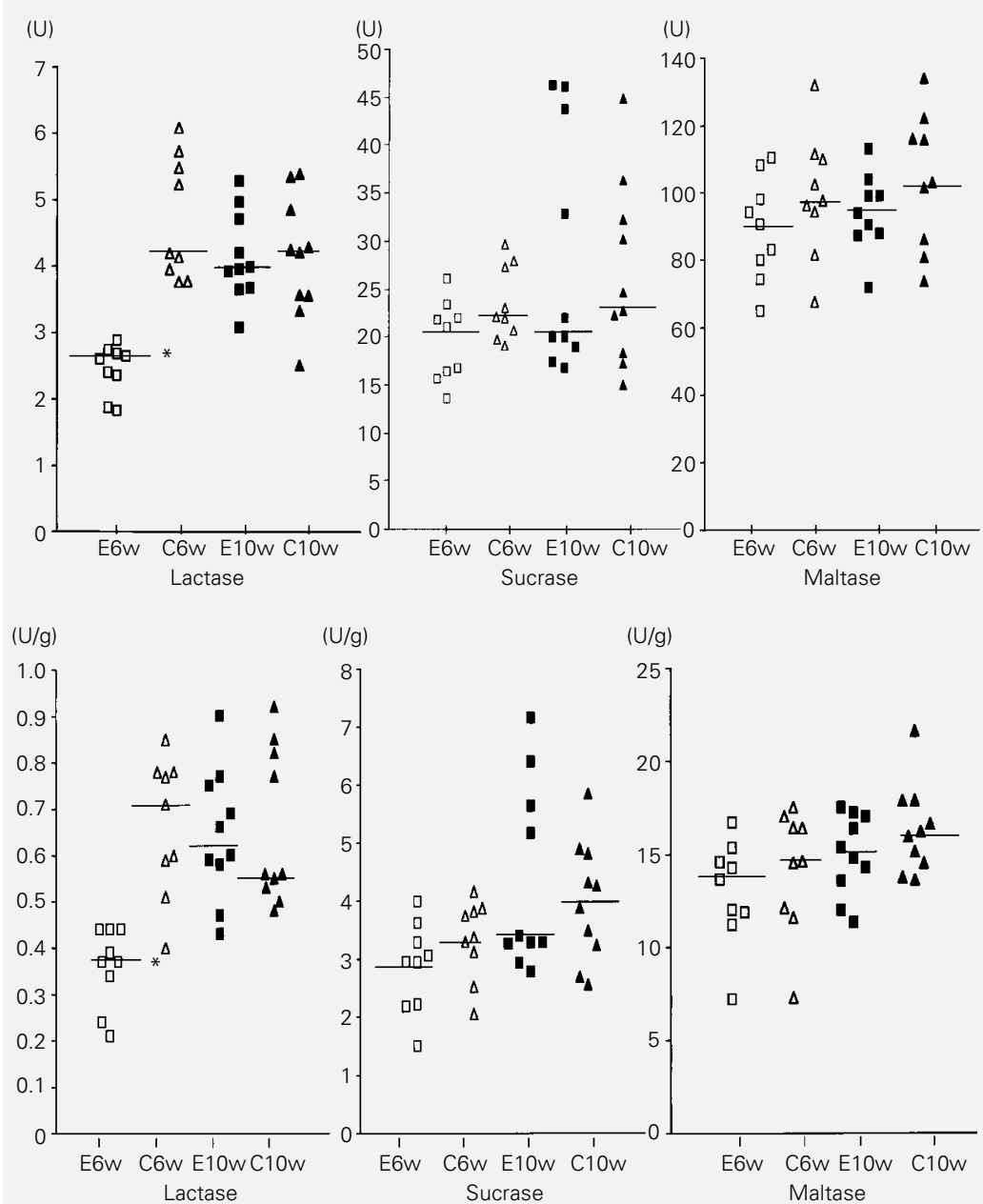

Figure 1 - Effect of anemia or recovery from anemia on total lactase, sucrase and maltase activity of the small intestine (top) and on specific enzyme activity per gram small intestine wet weight (bottom). Data are reported as individual values, with the median indicated by the horizontal bars. E6w = Anemic; E10w = recovered anemic; $\mathrm{C} 6 \mathrm{~W}$ and $\mathrm{C} 10 \mathrm{w}$ are the appropriate controls. ${ }^{*} \mathrm{P}<0.05$ compared to the other groups (nonparametric Mann-Whitney test). cantly between the experimental and control groups and these differences were not demonstrable after animal recovery.

Figure 2 shows the median and mean values for villus and crypt populations, MI, and cell production rate. No significant differences were detected between the groups.

\section{Discussion}

As expected, the animals in the experimental group presented anemia, with significantly decreased $\mathrm{Hb}, \mathrm{Ht}$, serum iron and transferrin saturation levels compared to the control group during the first 6 weeks of the experiment, with normalization occurring during the 4 weeks of recovery.

Lactase activity was markedly reduced in the anemic group both with respect to total activity and specific activity (Figure 1), in agreement with previous studies $(17,18)$. These investigators, however, also detected a significant reduction in sucrase and maltase, which was not demonstrated in the present study. Since lactase, because of its more superficial location, is known to be the first and most intensely affected enzyme in situations in which the villi are altered (35), this difference may be explained by the fact that, in the present study, the animals were submitted to a shorter period of anemia. Sriratanabam and Thayer (17) studied animals born to dams with iron-deficiency anemia that were suckled by their mothers and submitted to an iron-poor diet for an additional period of 75 to 185 days. Lanzkowsky et al. (18) studied a group of animals submitted to an iron-free diet from 21 to 84 days of age, i.e., for a period of 9 weeks. Dallman et al. (36), in a study of sucrase and maltase in the intestine of rats born to iron-deficient dams and fed an iron-free diet for 36 to 60 days, did not detect significant changes in either enzyme. These comparisons support the view that the duration of anemia, 6 weeks in our study, was probably insufficient to affect sucrase or maltase levels. 


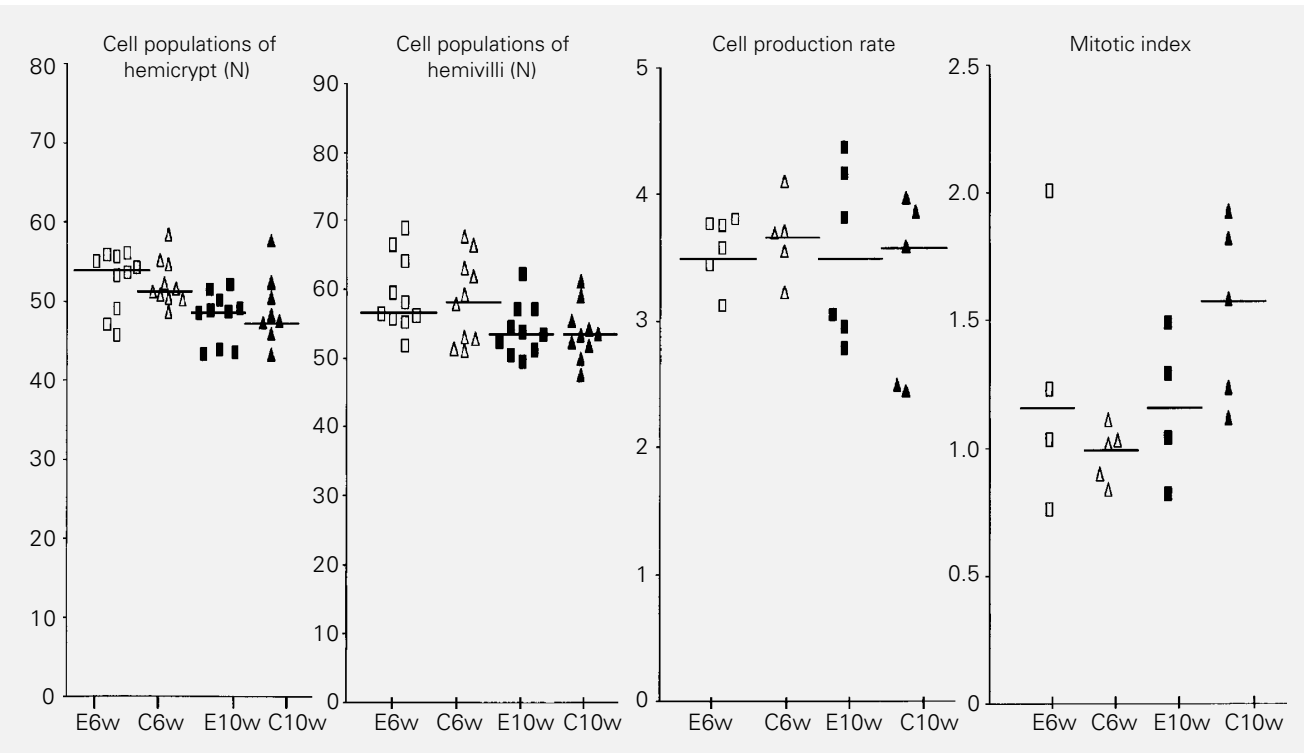

The reduction of weight in anemic animals as compared to the controls indicates the association of protein-calorie malnutrition with this nutritional disorder. Thus, malnutrition, and not iron deficiency, might be responsible for the reduction in lactase activity. This, however, seems to be unlikely, since total protein levels did not differ between anemic and control animals and the anemic animals, after refeeding, were able to recover TIBC levels. These data indicate that malnutrition was general and not limited to protein deficiency. Studies on the intestinal disaccharidases of malnourished rats have demonstrated the absence of interference of this type of disorder with disaccharidases in terms of specific activity $(37,38)$. Furthermore, the weight deficit was maintained throughout the period of recovery from anemia and in the present study there was recovery of lactase activity (Table 1).

The absence of differences in cell proliferation (Figure 2) suggests that this was not the mechanism responsible for the fall in lactase levels in the present study, supporting the finding of normal small bowel histology in anemia reported by others $(16,17)$. Thus, iron deficiency may probably be re- sponsible for a functional alteration of enterocytes, with reduced ability to synthesize lactase. The changes in protein profile at the intestinal level reported by Lanzkowsky et al. (18) in anemic rats reinforce this view. Dallman et al. (36) and Dallman (7) detected significant cytochrome $\mathrm{C}$ deficiency in the intestine of rats with iron-deficiency anemia. Since cytochrome $\mathrm{C}$ participates in cell respiration and in the production of oxidative energy, this deficiency may be the cause of this functional enterocyte disorder. These investigators did not determine lactase activity, but only sucrase and maltase activities, which were normal in anemic animals.

In conclusion, the present data support the existence of lactase deficiency in irondeficiency anemia, a fact that should be considered seriously in the treatment of diarrhea of children with this nutritional disorder. The data also suggest that the mechanism of iron-deficiency anemia is not due to an alteration in cell renewal in the small bowel.

\section{Acknowledgment}

We thank Laura Midori Kawasse for technical assistance in the cell proliferation study.
Figure 2 - Anemia and recovery from anemia had no effect on hemicrypt and hemivilli cell number or on cell production rate or mitotic index. Groups are the same as identified in the legend to Figure 1. The median values are given by the horizontal bars. There were no significant differences among groups (nonparametric Mann-Whitney test). 


\section{References}

1. Vizia B, Poggi V, Conenna R, Forillo A \& Scippa L (1992). Iron absorption and iron deficiency in infants and children with gastrointestinal diseases. Journal of Pediatric Gastroenterology and Nutrition, 14: 2126.

2. Oski FA (1993). Iron deficiency in infancy and childhood. New England Journal of Medicine, 329: 190-193.

3. Pallares I, Lisbona F, Aliage LI, Barrionueus M, Alferes MJM \& Campos MS (1993). Effect of iron deficiency on the digestive utilization of iron, phosphorus, calcium and magnesium in rats. British Journal of Nutrition, 70: 609-620.

4. Sigulen DN, Tudisco ES, Goldenberg P, Athaide MMM \& Vaisman E (1978). Anemia ferropriva em crianças do município de São Paulo. Revista de Saúde Pública, 12: 168-178.

5. Garcia PM (1995). Estudo longitudinal dos índices hematimétricos segundo o tipo de aleitamento em crianças de 0-12 meses de idade, nascidos no HC-FMRPUSP. Master's thesis, Faculdade de Medicina de Ribeirão Preto, Universidade de São Paulo, Ribeirão Preto.

6. Oski FA (1979). The non-hematologic manifestations of iron deficiency. American Journal of Diseases of Children, 133: 315-322.

7. Dallman PR (1982). Manifestations of iron deficiency. Seminars in Hematology, 19: 19-30.

8. Thibault $H$, Galan $P$, Selz F, Preziose $P$, Olimer C, Baldonal L \& Hercberg S (1993). The immune response in iron deficient young children: effect of iron supplementation on cell mediated immunity. European Journal of Pediatrics, 152: 120-124.

9. Jacobs A (1960). The buccal mucosa in anemia. Journal of Clinical Pathology, 13: 463-468.

10. Baird M, Dodge OG, Palmer FJ \& Wawmar RJ (1961). The tongue and oesophagus in iron-deficiency anaemia and the effect of iron therapy. Journal of Clinical Pathology, 14: 603-609.

11. Scott J, Valentine JA, Hill CA \& West CR (1985). Morphometric analysis of atrophic changes in human lingual epithelium in iron deficiency anaemia. Journal of Clinical Pathology, 38: 1025-1029.

12. Ranasinghe AW, Johnson NW \& Scragg MA (1987). Iron deficiency depresses cell proliferation in hamster cheek pouch epithelium. Cell and Tissue Kinetics, 20: 406412.
13. Ghosh S, Daga S, Kasthuri D, Misro RC \& Chutanni HK (1972). Gastrointestinal function in iron deficiency states in children. American Journal of Diseases of Children, 123: 14-17.

14. Guha DK, Walia BNS, Tandon BN, Deo MG \& Ghai OP (1968). Small bowel changes in iron-deficiency anaemia of childhood. Archives of Disease in Childhood, 43: 239-244.

15. Beraut $M$, Khourien $M$ \& Menzies IS (1992). Effect of iron deficiency on small intestinal permeability in infants and young children. Journal of Pediatric Gastroenterology and Nutrition, 14: 17-20.

16. Hoffbrand AV \& Broitman SA (1969). Effect of chronic nutritional iron deficiency on the small intestinal disaccharidase activities of growing dogs. Proceedings of the Society for Experimental Biology and Medicine, 130: 595-598.

17. Sriratanabam A \& Thayer WR (1971). Small intestinal disaccharidase activities in experimental iron and protein deficiency. American Journal of Clinical Nutrition, 24: 411-415.

18. Lanzkowsky $P$, Karayalcin $G$ \& Miller $F$ (1982). Disaccharidase level in iron deficient rats at birth and during the nursing and postweaning periods: Response to iron treatment. Pediatric Research, 16: 318-323.

19. Lanzkowsky $P$, Karayalcin G, Miller F \& Lane BP (1981). Disaccharidase values in iron deficient infants. Journal of Pediatrics, 99: 605-608.

20. Association of Official Analytical Chemists (1984). Official Methods of Analysis. 14th edn. Arlington.

21. McKay RH, Higuchi DA, Winder WW, Fell RD \& Brown EB (1983). Tissue effects of iron deficiency in the rat. Biochimica et Biophysica Acta, 757: 352-358.

22. Margoles MS (1984). Non-hematologic complications of iron deficiency. Nutrition Reviews, 42: 361-363.

23. Miale JB (1972). Laboratory Medicine Hematology. 4th edn. C.V. Mosby Co., St. Louis, 1214-1216.

24. Strumia MM, Sample AB \& Hart ED (1954). An improved micro hematocrit method. American Journal of Clinical Pathology, 24: 1016-1024.

25. Ramsay WNM (1957). The determination of iron in blood plasma or serum. Clinica Chimica Acta, 2: 214-220.

26. Ramsay WNM (1957). The determination of the total iron-binding capacity of serum. Clinica Chimica Acta, 2: 221-226.
27. Gornall AG, Bardawell CJV \& David MM (1949). Determination of serum proteins by means of the biuret reaction. Clinica Chimica Acta, 177: 751-766.

28. Dahlqvist A (1964). Method for assay of intestinal disaccharidases. Analytical Biochemistry, 7: 8-24

29. Wright NA (1980). Implications for proliferative responses in cell proliferation in the gastrointestinal tract. In: Appleton DR, Sunter JP \& Watson AJ (Editors), Cell Proliferation in the Normal Gastrointestinal Tract. Pitman Medical, Great Britain, 3-21.

30. Zucoloto S, Muccilo G, Wright NA \& Alison MR (1985). Chronic effects of alcohol on the epithelium of the small intestine using two experimental models. Virchows Archives of Biology and Cellular Pathology, 49: 365-373.

31. Liavag I (1970). Regeneration of bone marrow in relation to malignant disease. Acta Chirurgica Scandinavica, 136: 389399

32. Liavag I \& Vaage S (1972). The effect of vagotomy and pyloroplasty on the gastrointestinal mucosa of the rat. Scandinavian Journal of Gastroenterology, 7: 2327.

33. Tannock IF (1967). A comparison of the relative efficiencies of various metaphase arrest agents. Experimental Cell Research, 47: 345-356.

34. Snedecor GH \& Cochran WG (1967). Statistical Methods. The lowa State University Press, Ames, 130-134.

35. Boyle JT, Celano P \& Koldosky O (1980). Demonstration of a difference in expression of maximal lactase and sucrase activity along the villus in the adult rat jejunum. Gastroenterology, 79: 503-507.

36. Dallman PR, Sunshine $P$ \& Leonard $Y$ (1967). Intestinal cytochrome response with repair of iron deficiency. Pediatrics, 39: 863-871.

37. Galvão LC, Collares EF, Soares FC \& Brasil MRL (1978). Níveis das dissacaridases no intestino delgado de ratos lactentes submetidos à desnutrição protéicocalórica. Arquivos de Gastroenterologia, 15: 32-39.

38. Soares FC, Collares EF \& Brasil MRL (1973). Atividade total e específica da lactase, invertase e maltase no intestino delgado de ratos com subnutrição. Arquivos de Gastroenterologia, 12: 171177. 